J. Dairy Sci. 92:980-989

doi:10.3168/jds.2008-1636

(c) American Dairy Science Association, 2009.

\title{
Determination of milk and blood concentrations of lipopolysaccharide-binding protein in cows with naturally acquired subclinical and clinical mastitis
}

\author{
R. Zeng, ${ }^{*}$ B. J. Bequette, ${ }^{*}$ B. T. Vinyard, $\dagger$ and D. D. Bannerman $\neq^{1}$ \\ *Department of Animal and Avian Sciences, University of Maryland, College Park 20742 \\ †Biometrical Consulting Service, and \\ ¥Bovine Functional Genomics Laboratory, US Department of Agriculture, Agricultural Research Service, Beltsville, MD 20705
}

\begin{abstract}
Blood and milk concentrations of the acute phase protein lipopolysaccharide-binding protein (LBP) were evaluated in cows with naturally occurring mastitis. Blood and milk samples were collected from 101 clinically healthy dairy cows and 17 dairy cows diagnosed with clinical mastitis, and the LBP concentrations of the samples were measured by an ELISA. Concentrations of LBP were greater in the blood and milk of cows with clinical mastitis than in those with healthy quarters. Concentrations of LBP also differed between uninfected and subclinically infected quarters with low somatic cell count. Blood concentrations of LBP in cows with subclinical intramammary infections could not be differentiated from those of cows with all healthy quarters. Together, these data demonstrate that increased blood and milk concentrations of LBP can be detected in dairy cows with naturally acquired intramammary infections that cause clinical mastitis.
\end{abstract}

Key words: acute phase protein, dairy cow, innate immunity, mastitis

\section{INTRODUCTION}

In response to infection or inflammation, a rapid and nonspecific reaction known as the acute phase response (APR) is generally elicited by the host (Suffredini et al., 1999). The APR is characterized by changes in concentrations of a large number of plasma proteins, termed acute phase proteins (APP), produced predominantly by the liver (Pannen and Robotham, 1995). In cows with experimentally induced and naturally occurring mastitis, haptoglobin and serum amyloid A (SAA) concentrations have been shown to increase in both blood and milk, thus, serving as indicators of the inflammatory status of the udder (Eckersall et al.,

Received August 16, 2008.

Accepted October 27, 2008.

${ }^{1}$ Corresponding author: dbannerm@yahoo.com
2001; Ohtsuka et al., 2001; Pedersen et al., 2003). Correspondingly, both have been evaluated as biomarkers of intramammary infection and disease severity in cows with mastitis (Eckersall et al., 2001; Nielsen et al., 2004; Gronlund et al., 2005; Hiss et al., 2007).

Another APP that has been shown to be up-regulated during experimentally induced mastitis in cows is LPSbinding protein (LBP). Lipopolysaccharide-binding protein is a 58 - to $60-\mathrm{kDa}$ protein that catalyzes the transfer of bacterial LPS, a highly proinflammatory component of the outer wall of gram-negative bacteria, to CD14 (Tobias et al., 1999; Schumann and Latz, 2000). The protein CD14, which exists in a soluble form and as a cell surface receptor, facilitates LPS presentation to toll-like receptor-4. This, in turn, results in the activation of intracellular signaling pathways that promote the up-regulation of proinflammatory cytokines and adhesion molecules, which are involved in the host innate immune response to invading pathogens. In addition to bacterial LPS, LBP has been reported to facilitate host recognition of, and activation by, cell wall products of gram-positive bacteria (Fan et al., 1999; Schroder et al., 2003). Although detection of bacterial wall products is a key event in the activation of the innate immune response, excessive activation can lead to an exaggerated host response and the development of life-threatening septic shock (Dinarello, 1997). Data from several studies suggest that LBP may also aid in the detoxification of bacterial wall products, thus diminishing an excessive proinflammatory response that can be deleterious to the host (Wurfel et al., 1994; Vreugdenhil et al., 2003).

Concentrations of LBP have been shown to increase in the blood of calves experimentally infected with Mannheimia hemolytica (Horadagoda et al., 1995; Schroedl et al., 2001). In the setting of mastitis, LBP concentrations have been reported to increase in the blood and milk of cows following intramammary LPS challenge (Bannerman et al., 2003) and in response to experimentally induced intramammary infections (Bannerman et al., 2005; Kauf et al., 2007). In these 
studies, increases in milk concentrations of LBP temporally coincided with those in blood and occurred during a period of increased mammary vascular permeability. This finding suggests that the preponderance of LBP in milk during the APR to intramammary infection originates from leakage out of the blood vasculature. Interestingly, during experimentally induced mastitis following intramammary infusion of Escherichia coli, Mycoplasma bovis, or Pseudomonas aeruginosa, blood LBP concentrations have been shown to increase earlier, and remain elevated longer, than SAA (Bannerman et al., 2005, 2008; Kauf et al., 2007). This may indicate diagnostic value for LBP as a biomarker of underlying intramammary infection because prolonged increases in its concentration would be more likely to be detected than other APP with elevated concentrations of shorter duration. To date, there have been no published studies that have evaluated the concentrations of LBP in cows with naturally acquired mastitis. Therefore, the objective of this study was to compare the blood and milk concentrations of LBP among cows and quarters, respectively, that were healthy or had naturally acquired subclinical intramammary infections or clinical mastitis.

\section{MATERIALS AND METHODS}

\section{Animals}

Blood and milk samples were collected from lactating Holstein cows in the USDA-ARS Beltsville Area dairy herd. The use and care of all animals in this study were approved by the Beltsville Area Animal Care and Use Committee. Two experiments were conducted that involved sample collection from cows in the herd. In the first experiment, blood and milk samples were collected from 101 clinically healthy lactating cows. In the second experiment, all cows in the herd were monitored over a 4-mo period for visible signs of clinical mastitis, including abnormal milk secretions or quarters that were red, swollen, or hard. During this period, a total of 17 cows were diagnosed with clinical mastitis and sampled.

\section{Sample Collection}

Milk samples were aseptically collected by spraying each teat with an iodine-based disinfectant, forestripping, wiping off the disinfectant with a paper towel, and scrubbing each teat with sterilized gauze pads saturated with $70 \%$ ethanol. Following cleaning and disinfection of the teats, milk samples were collected into sterile tubes. Blood samples were drawn from the coccygeal vein of each animal using a 20-gauge Vacutainer needle and collected into glass tubes containing $\mathrm{K}_{2}$-EDTA (Becton Dickinson Corp., Franklin, Lakes, NJ).

\section{Whey and Plasma Preparation}

For the preparation of whey, milk samples were centrifuged at $44,000 \times g$ at $4^{\circ} \mathrm{C}$ for $30 \mathrm{~min}$ and the fat layer removed with a spatula. The skimmed milk was centrifuged again for $30 \mathrm{~min}$ as above, and the translucent supernatant collected, aliquotted, and stored at $-70^{\circ} \mathrm{C}$. For the preparation of plasma, blood samples were centrifuged at $1,500 \times g$ for $15 \mathrm{~min}$, and the clear supernatant was collected, aliquotted, and stored at $-70^{\circ} \mathrm{C}$.

\section{Quantification of Milk SCC and Diagnostic Microbiological Examination of Milk Samples}

For the quantification of somatic cells, milk samples were heated to $60^{\circ} \mathrm{C}$ and subsequently maintained at $40^{\circ} \mathrm{C}$ until the cells were counted on an automated milk somatic cell counter (Bentley Instruments Inc., Chaska, MN). For bacteriological analysis of milk samples collected during both experiments, all quarters were sampled twice over 2 consecutive days. Twenty and $100 \mu \mathrm{L}$ of each sample were plated on blood and MacConkey agar plates (Becton Dickinson Corp.), respectively. The plates were incubated for $24 \mathrm{~h}$ at $37^{\circ} \mathrm{C}$ and visually examined. If bacterial colonies were not evident, plates were incubated for an additional $24 \mathrm{~h}$ at $37^{\circ} \mathrm{C}$ and reexamined. Bacterial colonies were identified using standard microbiological procedures, including Gram staining and catalase and coagulase testing, in accordance with previously published guidelines (National Mastitis Council, 1999). When inconsistent bacteriological results were obtained from 2 samples from a given quarter, a third sample was collected and bacteriological analysis performed.

\section{ELISA for BSA, LBP, and Haptoglobin}

Concentrations of BSA were assayed using a commercially available ELISA (Bethyl Laboratories Inc., Montgomery, TX). The assay was performed as described previously (Bannerman et al., 2003) with the exception that wells were coated with $10 \mu \mathrm{g} / \mathrm{mL}$ of sheep antibovine BSA antibodies for $1 \mathrm{~h}$ at room temperature instead of overnight at $4^{\circ} \mathrm{C}$. Whey samples were diluted between 1:2,500 and 1:60,000 so that they were within the linear range of the assay. Concentrations of LBP were determined with a commercially available ELISA kit (Cell Sciences Inc., Canton, MA) as described previously (Bannerman et al., 2003). Whey samples were diluted between 1:10 and 1:9,000 and plasma samples diluted between 1:500 and 1:4,500 so that they were within the linear range of the assay. 
Table 1. Bacteriological analysis of milk samples from cows that were either clinically healthy and had at least one subclinically infected quarter or had at least one quarter diagnosed with clinical mastitis ${ }^{1}$

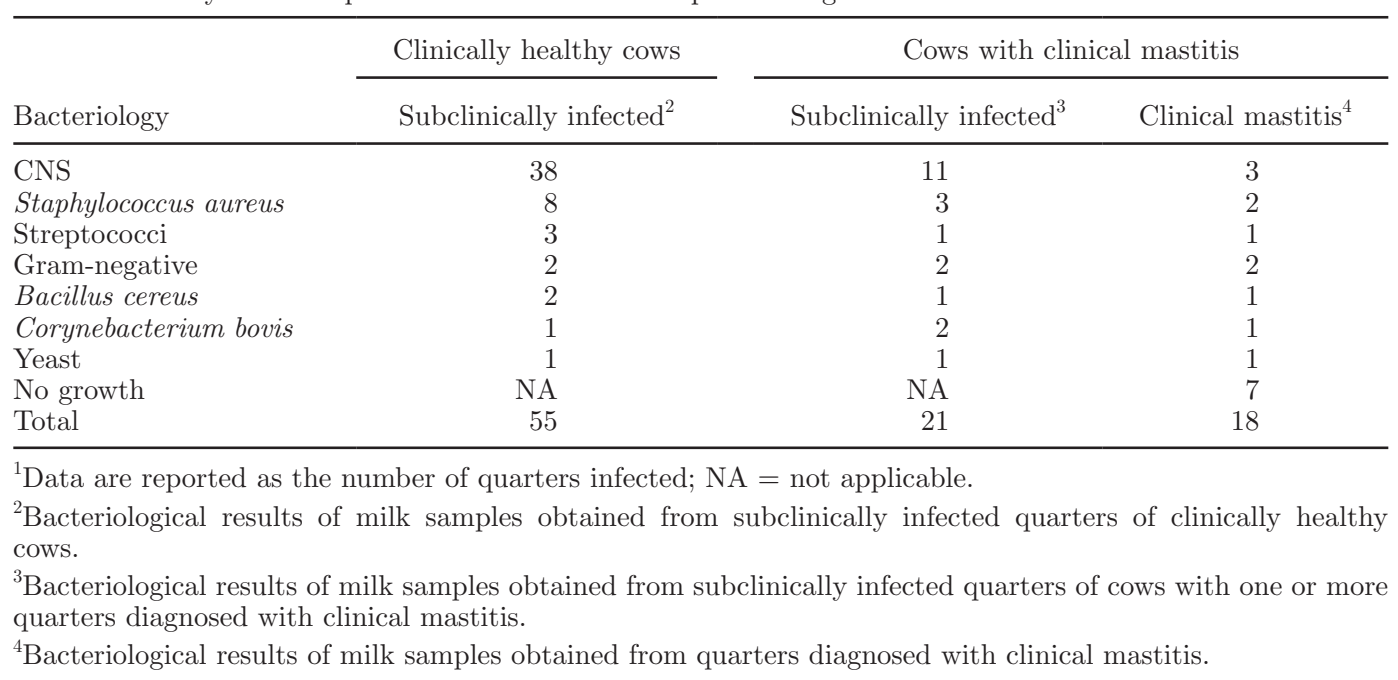

Haptoglobin concentrations were determined with a commercially available ELISA kit (Alpco Diagnostics, Salem, NH) according to the manufacturer's instructions. Whey samples were diluted between 1:10 and 1:500 and plasma samples diluted between 1:100 and $1: 10,000$ so that they were within the linear range of the assay. Plates were analyzed at a wavelength of 450 $\mathrm{nm}$ and a correction wavelength of $565 \mathrm{~nm}$ using a microplate reader (Bio-Tek Instruments Inc., Winooski, VT). The concentrations of haptoglobin in the samples were calculated by extrapolation from a standard curve of known amounts of bovine haptoglobin.

\section{Statistical Methods}

A GLM with lognormal distribution and identity link was fit to each dependent variable using Proc GLIMMIX (SAS Institute, 2006). For the analysis of the effects and interaction of bacteriological status (i.e., noninfected or infected) and SCC (i.e., $\leq 250,000$ or $>250,000$ cells $/ \mathrm{mL}$ ) on a given dependent variable in samples derived from healthy and subclinically infected cows, a 2-way ANOVA model was specified. For the analysis of the effects of the type of infection (i.e., clinically infected, subclinically infected, or noninfected) on a given dependent variable, a one-way ANOVA model was specified. Significant differences, $\alpha=0.05$, among treatment means were identified using the Extended Shaffer-Royen multiple comparisons method (Westfall and Tobias, 2007) by specifying ADJUST = SIMULATE and STEPDOWN options in the LSMEANS statement (SAS Institute, 2006). A $P$-value of $<0.05$ was considered significant.

\section{RESULTS}

\section{Bacteriological Results and SCC of Milk Samples from Subclinically Infected Cows}

Milk samples were collected from 393 quarters of 101 clinically healthy cows. Of the samples plated, 55 were positive for bacterial growth, and the quarters from which these samples were derived were classified as subclinically infected. Diagnostic microbiological testing identified CNS as the most prevalent pathogen among the subclinically infected quarters (Table 1). The second most prevalent pathogen isolated was Staphylococcus aureus. Together, these 2 pathogens accounted for $84 \%$ of the subclinical intramammary infections. Other pathogens isolated included Streptococcus spp., gram-negative bacilli, Bacillus cereus, Corynebacterium bovis, and yeast.

The milk SCC of the 55 subclinically infected quarters $\left(851 \pm 319 \times 10^{3}\right.$ cells $\left./ \mathrm{mL}\right)$ were approximately 9-fold higher $(P<0.0001)$ than those of the noninfected quarters $\left(86 \pm 13 \times 10^{3}\right.$ cells $/ \mathrm{mL}$; Figure 1A). For subsequent analysis of the effect of SCC on milk APP concentrations, samples were also analyzed on the basis of defined grouping by low $(\leq 250,000$ cells $/ \mathrm{mL})$ or high $(>250,000$ cells $/ \mathrm{mL})$ SCC regardless of infection status (Figure 1B). Correspondingly, there was a significant difference in SCC between the 2 groups $(P$ $<0.0001)$. Samples were also analyzed on the basis of both infection status and SCC grouping (Figure 1C). Of the 347 quarters with milk SCC $\leq 250,000$ cells $/ \mathrm{mL}$, $36(\sim 10 \%)$ were positive for bacterial growth. The SCC of these quarters $\left(94 \pm 11 \times 10^{3}\right.$ cells $\left./ \mathrm{mL}\right)$ differed $(P<0.0001)$ from those of noninfected quarters $(40$ 
A
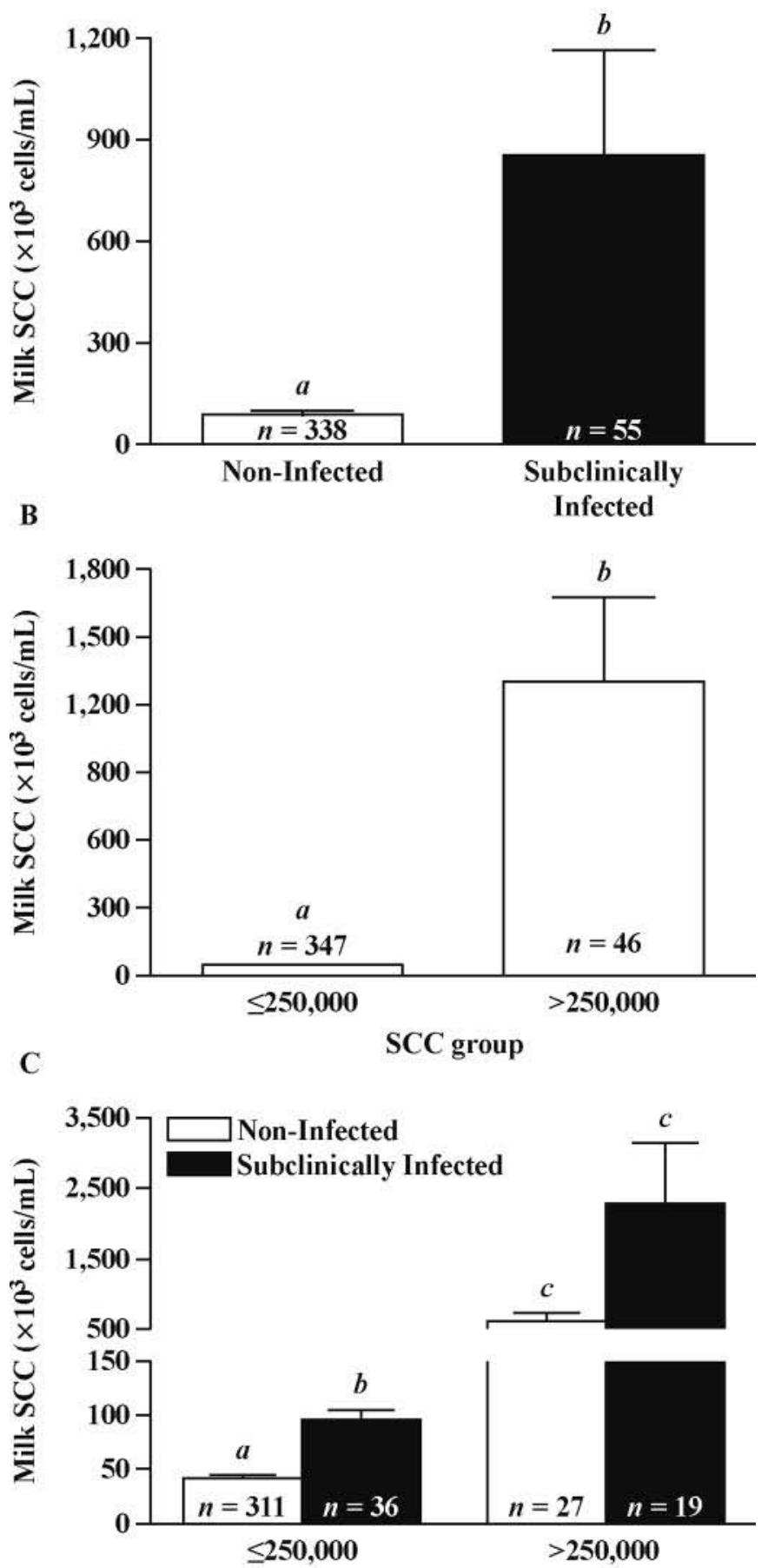

SCC group

Figure 1. Somatic cell counts of milk samples obtained from clinically healthy cows. Milk samples were collected from 393 quarters of 101 clinically healthy cows and analyzed for SCC. Data are presented on the basis of A) infection status (noninfected vs. subclinically infected), B) SCC grouping ( $\leq 250,000$ vs. $>250,000$ cells $/ \mathrm{mL}$ ), or both $(\mathrm{C})$, and reported as mean $( \pm \mathrm{SE})$ counts in thousands per milliliter. ${ }^{\mathrm{a}-\mathrm{C}}$ Different letters denote statistically significant $(P<0.05)$ differences between groups. $\pm 3 \times 10^{3}$ cells $/ \mathrm{mL}$ ) in the low SCC group. Of the 46 quarters with milk SCC $>250,000$ cells $/ \mathrm{mL}, 19(\sim 41 \%)$ were positive for bacterial growth. The SCC of these quarters $\left(2,284 \pm 841 \times 10^{3}\right.$ cells $\left./ \mathrm{mL}\right)$ approached but did not reach a level that was significantly different $(P$ $=0.0865)$ from those of noninfected quarters $(616 \pm$ $114 \times 10^{3}$ cells $/ \mathrm{mL}$ ) in the high SCC group.

\section{BSA Concentrations of Milk Samples from Subclinically Infected Cows}

Milk BSA concentrations were assayed as a marker of local inflammation in milk samples collected from the healthy and subclinically infected quarters of clinically healthy cows. On the basis of infection status alone, there were no significant differences in the BSA concentrations of milk samples obtained from subclinically infected versus noninfected quarters (Figure 2A). On the basis of SCC grouping alone, milk BSA concentrations were greater $(P=0.0265)$ in milk samples with $\mathrm{SCC}>250,000$ cells $/ \mathrm{mL}(388 \pm 37 \mu \mathrm{g} / \mathrm{mL})$ than in those with $\mathrm{SCC} \leq 250,000$ cells $/ \mathrm{mL}(300 \pm 14 \mu \mathrm{g} / \mathrm{mL}$; Figure 2B). Analysis of samples on the basis of both SCC grouping and infection status identified comparable milk BSA concentrations among samples from subclinically infected and noninfected quarters in the low SCC group, as well as between those from subclinically infected and noninfected quarters in the high SCC group (Figure 2C).

\section{LBP Concentrations Are Greater in Quarters with Low Milk SCC That Are Subclinically Infected Compared with Those That Are Uninfected}

On the basis of infection status alone, milk LBP concentrations were comparable between the noninfected and subclinically infected quarters of clinically healthy cows (Figure 3A). On the basis of SCC grouping, irrespective of infection status, milk LBP concentrations were greater $(P=0.0032)$ in milk samples with SCC $>250,000$ cells $/ \mathrm{mL}(12.78 \pm 1.39 \mu \mathrm{g} / \mathrm{mL})$ than in those with SCC $\leq 250,000$ cells $/ \mathrm{mL}(6.20 \pm 0.33 \mu \mathrm{g} / \mathrm{mL}$; Figure $3 \mathrm{~B}$ ). Analysis of samples on the basis of both SCC grouping and infection status revealed a significant difference $(P=0.0357)$ in milk LBP concentrations between noninfected and subclinically infected quarters where SCC were $\leq 250,000$ cells $/ \mathrm{mL}$ (Figure 3C). In samples with high SCC $(>250,000$ cells $/ \mathrm{mL})$, there were no significant differences $(P=0.1699)$ in milk LBP concentrations between noninfected and subclinically infected quarters. 


\section{Milk Haptoglobin Concentrations Are Greater in Subclinically Infected Quarters Compared with Those That Are Uninfected}

On the basis of infection status alone, milk haptoglobin concentrations were greater $(P=0.0013)$ in those quarters that were subclinically infected $(4.12 \pm$ $1.65 \mu \mathrm{g} / \mathrm{mL})$ than in those that were uninfected $(0.82$ $\pm 0.21 \mu \mathrm{g} / \mathrm{mL}$; Figure 4A). On the basis of SCC grouping, irrespective of infection status, milk haptoglobin concentrations were greater $(P<0.0001)$ in milk samples with SCC $>250,000$ cells $/ \mathrm{mL}(7.18 \pm 2.10 \mu \mathrm{g} / \mathrm{mL})$ than in those with SCC $\leq 250,000$ cells $/ \mathrm{mL}(0.50 \pm 0.15$ $\mu \mathrm{g} / \mathrm{mL}$; Figure 4B). Analysis of samples on the basis of both SCC grouping and infection status revealed a significant difference $(P=0.0001)$ in milk haptoglobin concentrations between noninfected and subclinically infected quarters where SCC were $\leq 250,000$ cells $/ \mathrm{mL}$ (Figure 4C). In samples with high SCC (>250,000 cells/ $\mathrm{mL})$, there were no significant differences $(P=0.1927)$ in milk haptoglobin concentrations between noninfected and subclinically infected quarters.

\section{Bacteriological Results, SCC, and BSA Concentrations of Milk Samples from Cows with Clinical Mastitis}

Milk samples were collected from 17 cows with naturally occurring clinical mastitis. Samples were obtained at the first sign of clinical mastitis during the morning or evening milking and collected from all quarters. With the exception of one cow that had clinical symptoms in 2 quarters, all other cows sampled had only one quarter with clinical mastitis. Of the milk samples isolated from the remaining quarters showing no clinical signs of disease, 21 were positive for bacterial growth and the corresponding quarters classified as subclinically infected. Among the quarters of these cows that showed either clinical mastitis or were subclinically infected, CNS, Staph. aureus, and gram-negative bacilli were the most prevalent bacteria recovered (Table 1). Twentytwo quarters were free of infection and had milk SCC $\leq 250,000$ cells $/ \mathrm{mL}$. These quarters were classified as healthy based on the absence of infection and inflammation.

Among the cows with clinical mastitis, the milk SCC of the quarters with clinical signs $(18,553 \pm 9,596 \times$ $10^{3}$ cells $\left./ \mathrm{mL}\right)$ were approximately 42 -fold higher $(P=$ $0.0002)$ than those of subclinically infected quarters $\left(434 \pm 175 \times 10^{3}\right.$ cells $/ \mathrm{mL}$; Figure $\left.5 \mathrm{~A}\right)$. The SCC of the healthy quarters of these cows $\left(44 \pm 10 \times 10^{3}\right.$ cells $\left./ \mathrm{mL}\right)$ were lower than those of the quarters showing clinical signs $(P<0.0001)$ or that were subclinically infected
A
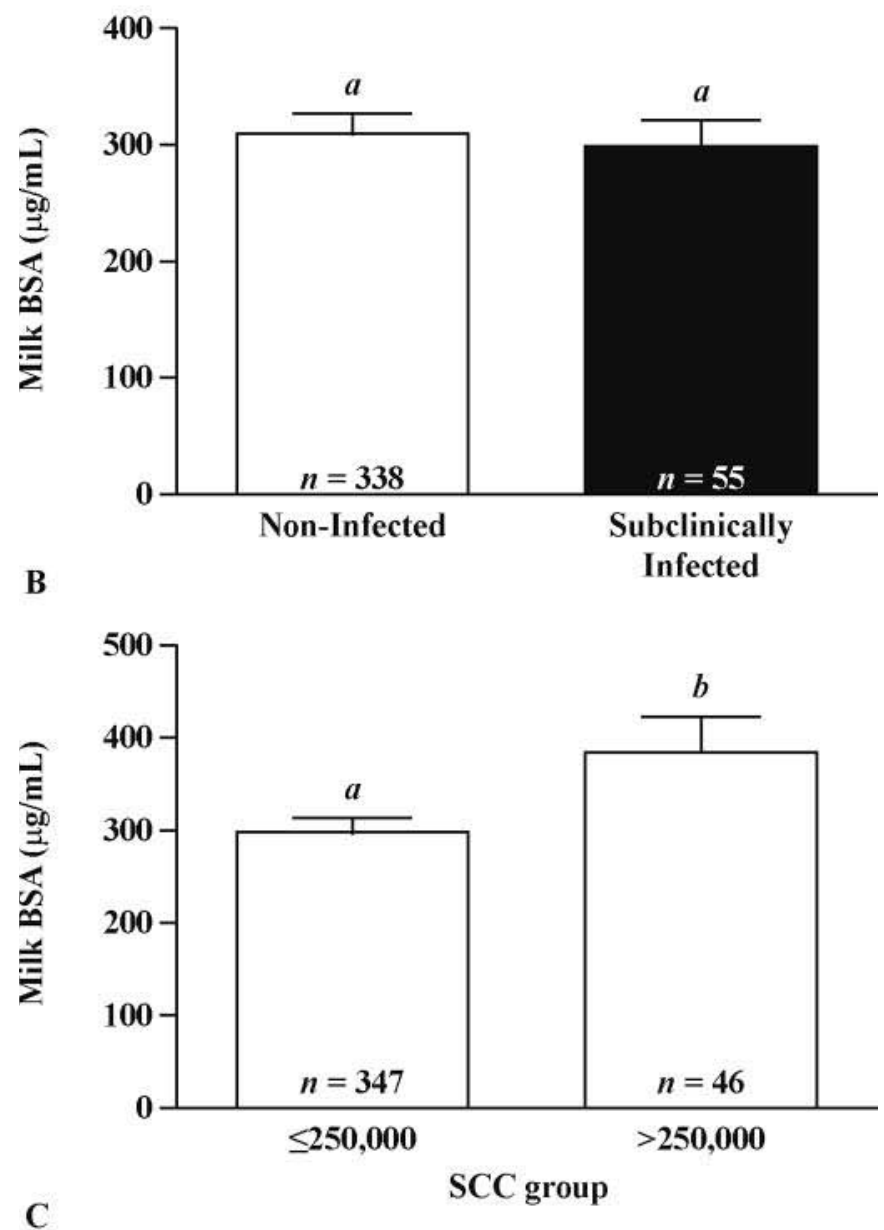

C

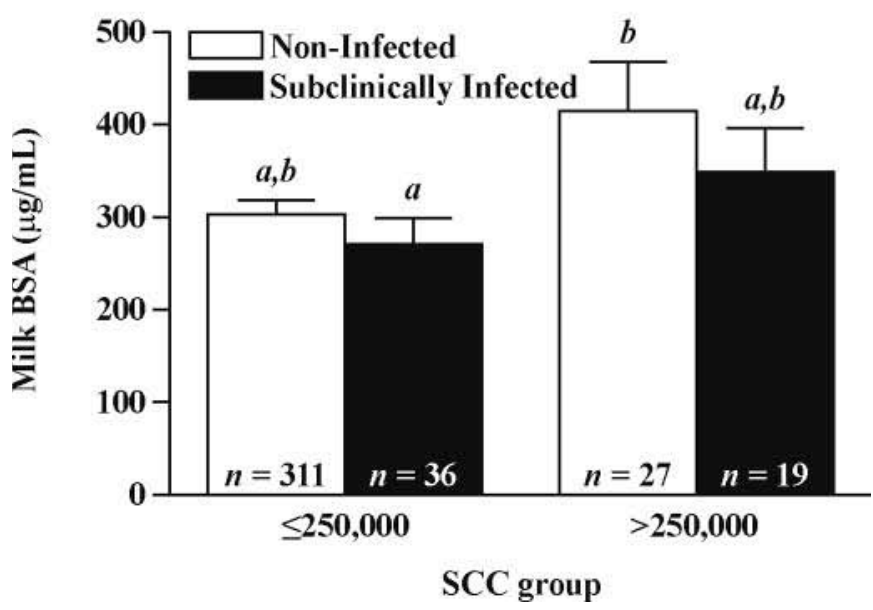

Figure 2. Concentrations of BSA in milk samples obtained from clinically healthy cows. The BSA concentrations of milk samples collected from 393 quarters of 101 clinically healthy cows were determined by ELISA. Data are presented on the basis of A) infection status (noninfected vs. subclinically infected), B) SCC grouping ( $<250,000$ vs. $>250,000$ cells $/ \mathrm{mL})$, or both $(\mathrm{C})$, and reported as mean $( \pm \mathrm{SE})$ milk BSA concentrations in micrograms per milliliter. ${ }^{a, b}$ Different letters denote statistically significant $(P<0.05)$ differences between groups. 
A
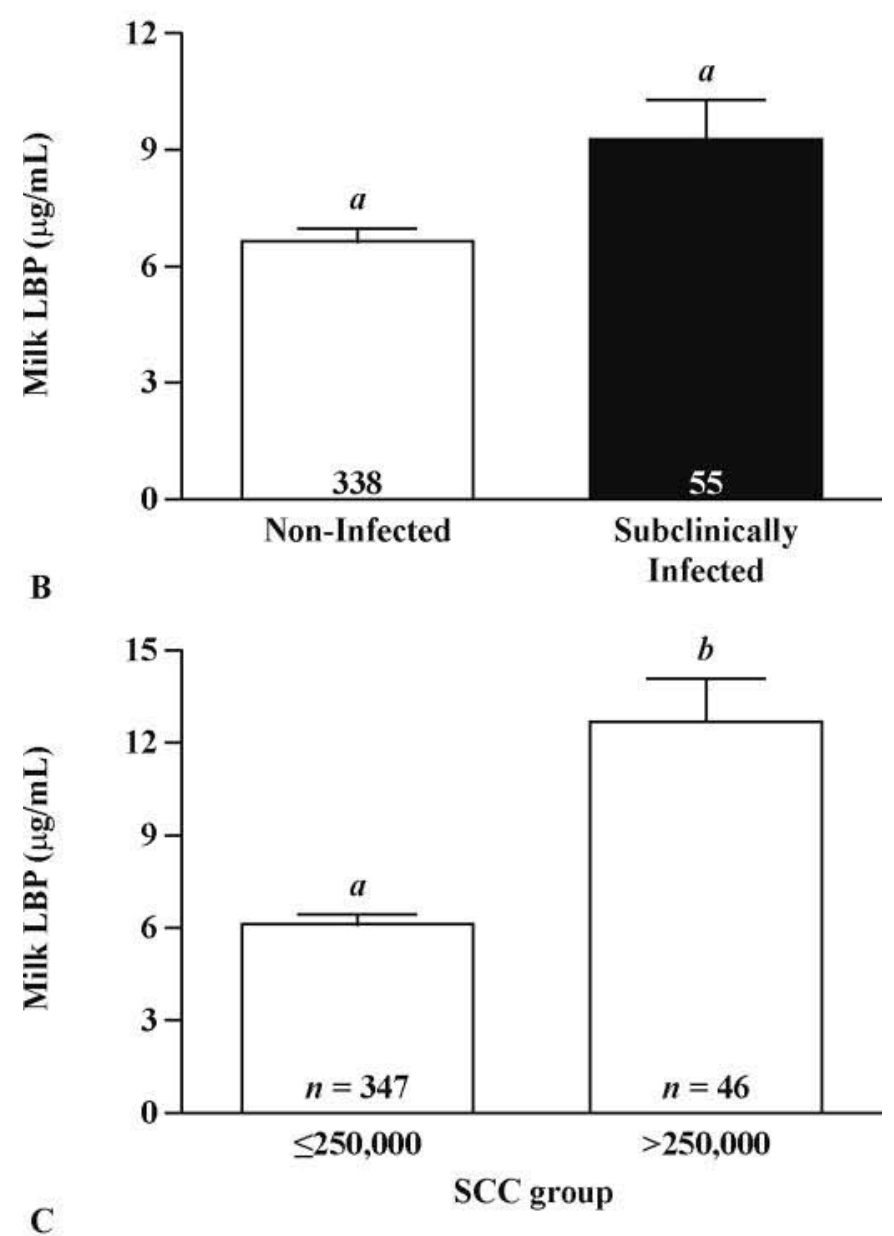

C

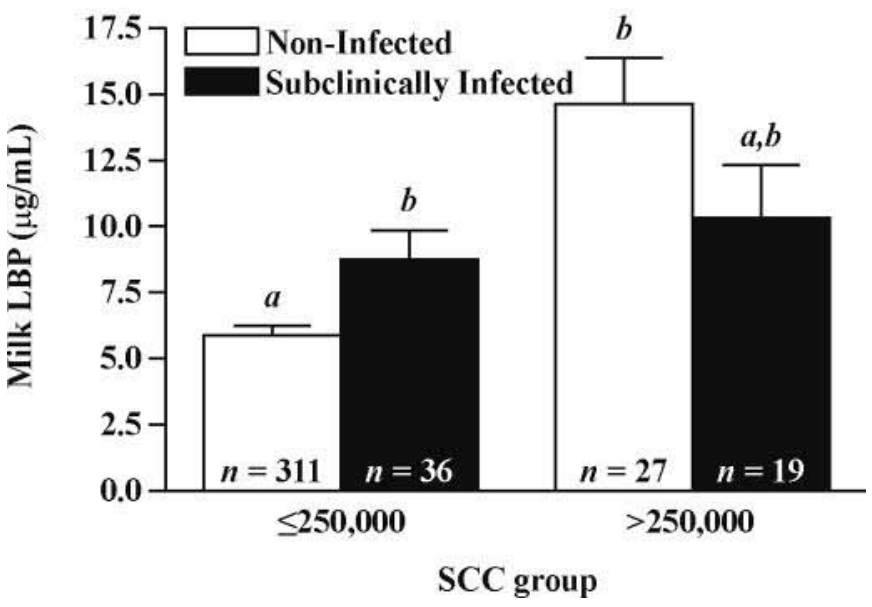

Figure 3. Lipopolysaccharide-binding protein (LBP) concentrations in milk samples obtained from clinically healthy cows. The LBP concentrations of milk samples collected from 393 quarters of 101 clinically healthy cows were determined by ELISA. Data are presented on the basis of A) infection status (noninfected vs. subclinically infected), B) SCC grouping ( $\leq 250,000$ vs. $>250,000$ cells $/ \mathrm{mL}$ ), or both (C), and reported as mean $( \pm \mathrm{SE})$ milk LBP concentrations in micrograms per milliliter. ${ }^{\mathrm{a}, \mathrm{b}}$ Different letters denote statistically significant $(P<0.05)$ differences between groups.
$(P=0.0189)$. The milk BSA concentrations of these cows were greater in the quarters with clinical mastitis $(2,143 \pm 1,054 \mu \mathrm{g} / \mathrm{mL})$ than in those quarters that had a subclinical infection $(329 \pm 37 \mu \mathrm{g} / \mathrm{mL} ; P=0.0204)$ or were healthy $(374 \pm 170 \mu \mathrm{g} / \mathrm{mL} ; P=0.0021$; Figure 5B). There was no difference $(P=0.2371)$ between the milk BSA concentrations of the noninfected and subclinically infected quarters of these cows.

\section{LBP and Haptoglobin Concentrations of Milk Samples from Cows with Clinical Mastitis}

In cows with clinical mastitis, those quarters that showed clinical signs of disease $(19.64 \pm 4.50 \mu \mathrm{g} / \mathrm{mL})$ or were subclinically infected $(17.29 \pm 3.64 \mu \mathrm{g} / \mathrm{mL})$ had greater $(P=0.0464$ and 0.0489 , respectively) milk concentrations of LBP than corresponding healthy quarters $(8.37 \pm 2.61 \mu \mathrm{g} / \mathrm{mL}$; Figure $5 \mathrm{C})$. There was no difference $(P=0.5979)$, however, in the milk LBP concentrations of the quarters of these cows that showed clinical signs versus those quarters that were subclinically infected. Similar to LBP, milk haptoglobin concentrations in quarters with clinical signs $(78.72 \pm$ $47.28 \mu \mathrm{g} / \mathrm{mL})$ or subclinical infections $(12.27 \pm 3.80$ $\mu \mathrm{g} / \mathrm{mL})$ were greater $(P<0.0001$ and $P=0.0003$, respectively) than those in the healthy quarters $(3.45$ $\pm 2.20 \mu \mathrm{g} / \mathrm{mL}$ ) of the same cows (Figure 5D). The haptoglobin concentrations of milk samples obtained from the quarters of these cows that were subclinically infected versus those that demonstrated clinical signs differed by a level that approached $(P=0.0666)$ statistical significance.

\section{Blood LBP and Haptoglobin Concentrations Are Greater in Cows with Clinical Mastitis Than in Cows with Subclinical Intramammary Infections or All Healthy Quarters}

Blood samples were also obtained from the 17 cows diagnosed with clinical mastitis. For comparison, blood samples obtained from the 101 clinically healthy cows were segregated into 2 groups, those from cows with all 4 quarters that were free of infection and had milk SCC $\leq 250,000$ cells $/ \mathrm{mL}(\mathrm{n}=47)$ and those from cows with one or more quarters that were subclinically infected $(\mathrm{n}=39)$.

Blood concentrations of LBP were greater in cows with clinical mastitis $(113.12 \pm 17.48 \mu \mathrm{g} / \mathrm{mL})$ than in those with subclinical intramammary infections (35.10 $\pm 6.31 \mu \mathrm{g} / \mathrm{mL} ; P<0.0001)$ or all healthy quarters $(23.16 \pm 3.19 \mu \mathrm{g} / \mathrm{mL} ; P<0.0001 ;$ Figure $6 \mathrm{~A})$. There was no difference $(P=0.1390)$ between the blood LBP concentrations of noninfected cows and those with subclinical intramammary infections. Similar to LBP, 

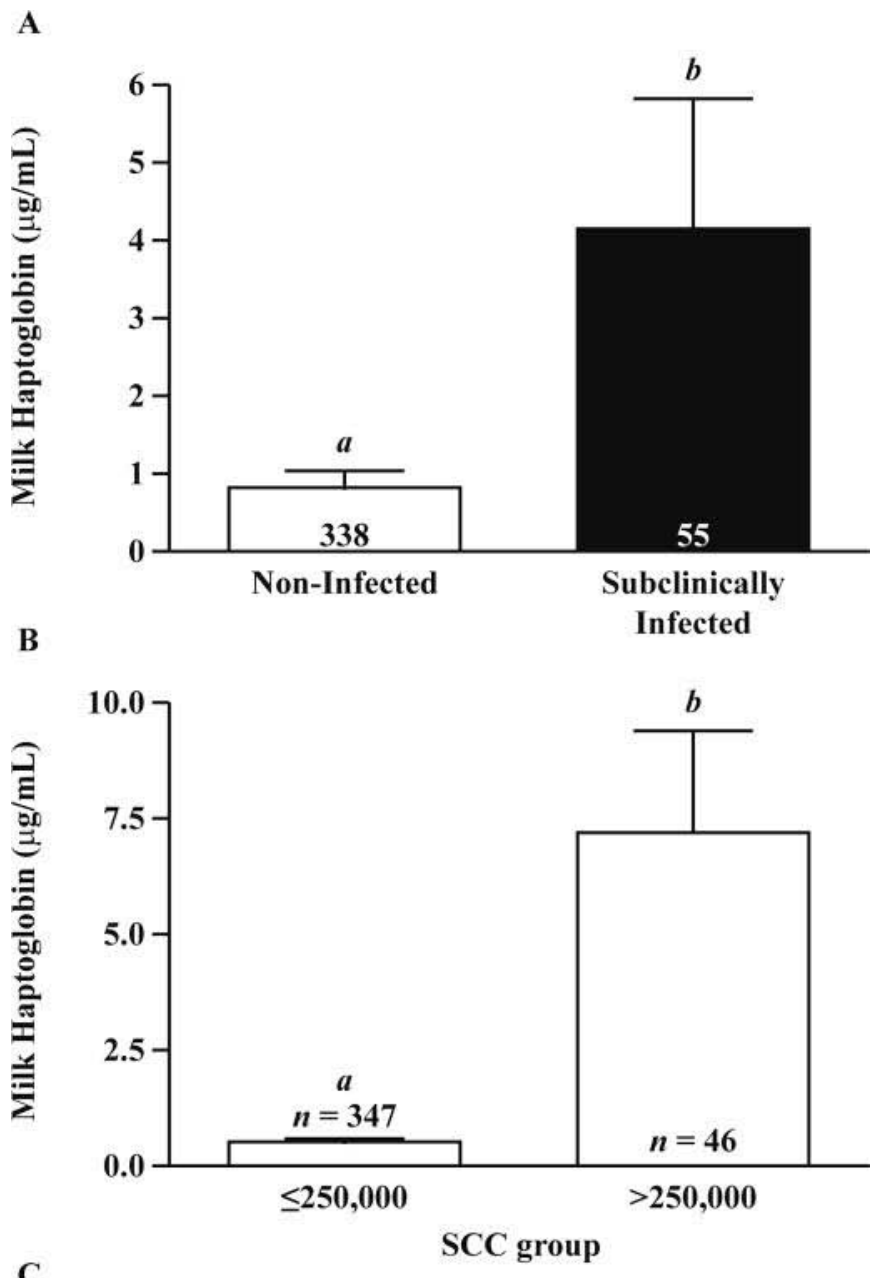

C

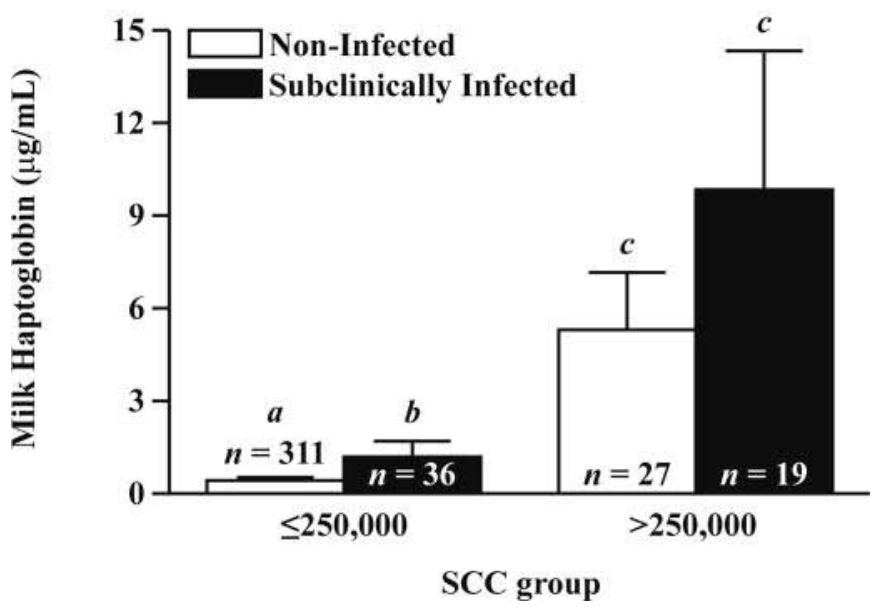

Figure 4. Haptoglobin concentrations in milk samples obtained from clinically healthy cows. The haptoglobin concentrations of milk samples collected from 393 quarters of 101 clinically healthy cows were determined by ELISA. Data are presented on the basis of A) infection status (noninfected vs. subclinically infected), B) SCC grouping ( $\leq 250,000$ vs. $>250,000$ cells $/ \mathrm{mL}$ ), or both $(\mathrm{C})$, and reported as mean $( \pm$ SE) milk haptoglobin concentrations in micrograms per milliliter. ${ }^{\mathrm{a}-\mathrm{c}}$ Different letters denote statistically significant $(P<0.05)$ differences between groups. blood haptoglobin concentrations were significantly $(P$ $<0.0001$ ) greater in cows with clinical mastitis than in cows with all healthy quarters or at least one quarter with a subclinical infection (Figure 6B). In contrast to LBP, the concentrations of haptoglobin were greater $(P$ $=0.0499)$ in the blood of cows with a subclinical intramammary infection versus those with all healthy quarters. The blood concentrations of haptoglobin in cows with all healthy quarters, subclinical intramammary infections, or clinical mastitis were $1.45 \pm 0.7,23.31 \pm$ 13.16 , and $1,732.61 \pm 314.27 \mu \mathrm{g} / \mathrm{mL}$, respectively.

\section{DISCUSSION}

The current study investigated the effects of naturally occurring subclinical intramammary infection and clinical mastitis on the milk and blood concentrations of APP in dairy cows. The frequency distribution of the pathogens identified in this study in the milk samples from subclinically infected cows and those with clinical mastitis were consistent with previously published surveys (Makovec and Ruegg, 2003; Bradley et al., 2007). Further, the predominance of the absence of bacterial growth in the plated milk samples from quarters with clinical mastitis is consistent with a previous report (Bradley et al., 2007). Thus, the distribution of bacterial pathogens isolated from quarters in this study was reflective of that observed in other herds.

Several studies have suggested that a SCC threshold value of 200,000 to 300,000 cells/mL has diagnostic value for distinguishing between uninfected and infected quarters, and consequently, noninflamed versus inflamed quarters (Dohoo and Meek, 1982; Schepers et al., 1997; Schukken et al., 2003). In the current study, APP concentrations were analyzed in samples from clinically healthy cows on the basis of bacterial growth in plated milk samples, as well as on the basis of an SCC threshold of 250,000 cells $/ \mathrm{mL}$, the latter of which was chosen based on the findings of the previously mentioned studies. In cows with clinical mastitis, the APP concentrations in samples from quarters showing clinical signs were compared with those in samples from quarters of the same cows that either had a subclinical infection (i.e., positive for bacterial growth on plated milk samples) or had SCC $\leq 250,000 \mathrm{cell} / \mathrm{mL}$ and no bacterial growth. This experimental design allowed for the comparison of APP concentrations from quarters showing clinical signs, or that were subclinically infected, to APP concentrations in healthy quarters as defined by the combination of both low SCC and absence of bacterial growth.

For the analysis of milk samples, LBP concentrations were determined in whey. Because a potential interaction between LBP and milk fat components cannot 
A

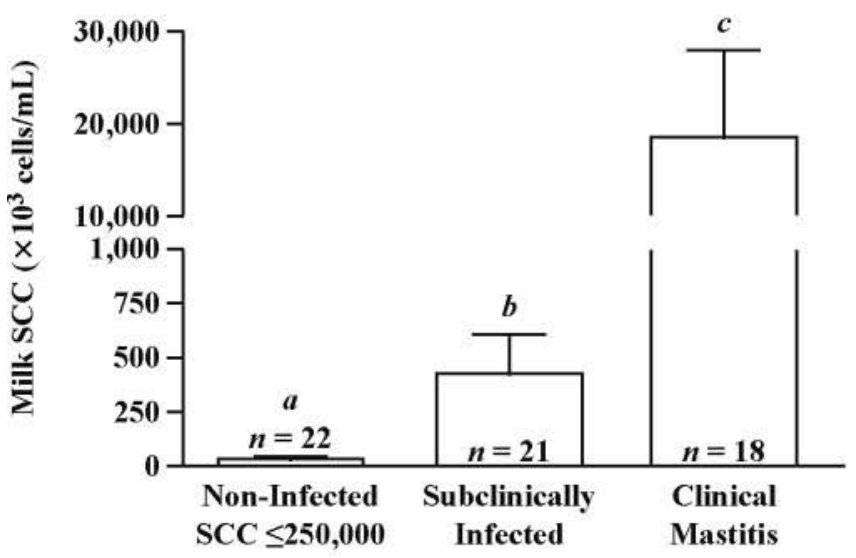

C

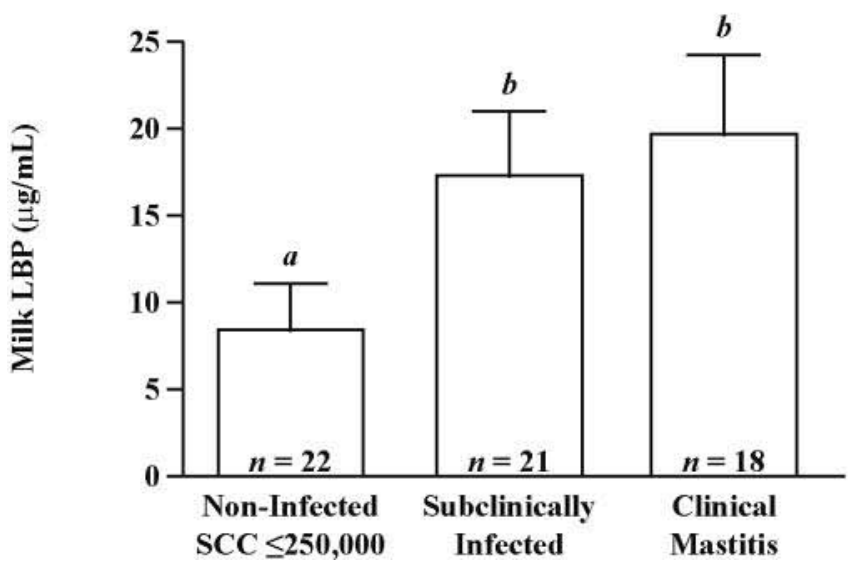

B

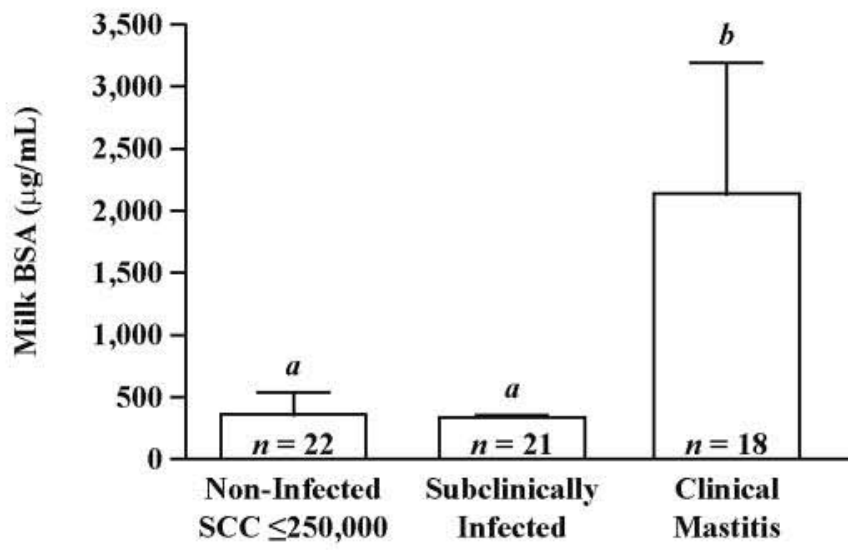

D

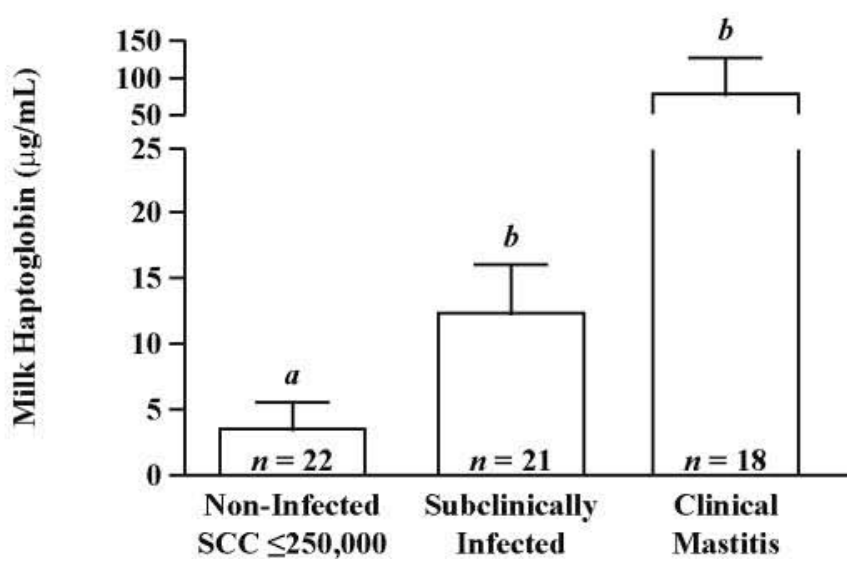

Figure 5. Measurement of indices of inflammation in milk samples obtained from cows with clinical mastitis. Milk samples were collected from all quarters of 17 cows diagnosed with clinical mastitis in one or more quarters. Milk samples from the quarters were divided into 3 groups on the basis of 1) absence of bacterial growth after plating, SCC $\leq 250,000$ cells $/ \mathrm{mL}$, and absence of any clinical signs of disease in the quarter from which the sample was collected; 2) presence of bacterial growth and absence of any clinical signs of disease in the quarter from which the sample was collected (subclinically infected); and 3) presence of clinical signs of disease in the quarter from which the sample was collected (clinical mastitis). The milk SCC of the samples were determined and reported as mean ( $\pm \mathrm{SE})$ counts in thousands per milliliter (A); BSA (B), LPS-binding protein (LBP) (C), and haptoglobin (D) concentrations in the samples were determined by ELISA and reported as mean ( \pm SE) concentrations in micrograms per milliliter. ${ }^{a-c}$ Different letters denote statistically significant $(P<0.05)$ differences between groups.

be ruled out, the concentrations reported in this study may be lower than those found in the mammary gland. Because bound LBP would be expected to be impaired in its ability to moderate immune-inflammatory responses, measurement of free (i.e., non-fat-associated) LBP allowed for the detection of changes in the concentrations of LBP with maximal biological activity.

Results from the current study demonstrate that relative to cows with all healthy quarters, blood LBP concentrations are elevated in cows with clinical mastitis but not in those with subclinical infections (Figure $6 \mathrm{~A})$. In clinically healthy cows with low SCC, milk LBP concentrations were greater in subclinically infected quarters than in noninfected quarters (Figure 3C). However, when SCC were not taken into consideration, milk LBP concentrations did not differ between sub- clinically infected and uninfected quarters in clinically healthy cows (Figure 3A). Interestingly, LBP concentrations were greater in the subclinically infected quarters of cows with clinical mastitis than in the healthy quarters of these same cows (Figure 5C). This may be due, in part, to the increased availability of LBP that can diffuse into these quarters as a result of increased circulating blood concentrations of LBP in cows with clinical mastitis.

For comparison with LBP, the current study also investigated the influence of subclinical intramammary infection and clinical mastitis on milk and blood concentrations of haptoglobin, an APP which has been widely studied as a diagnostic marker of udder health (Hirvonen et al., 1999; Eckersall et al., 2001; Nielsen et al., 2004; Gronlund et al., 2005; Hiss et al., 2007). 
A

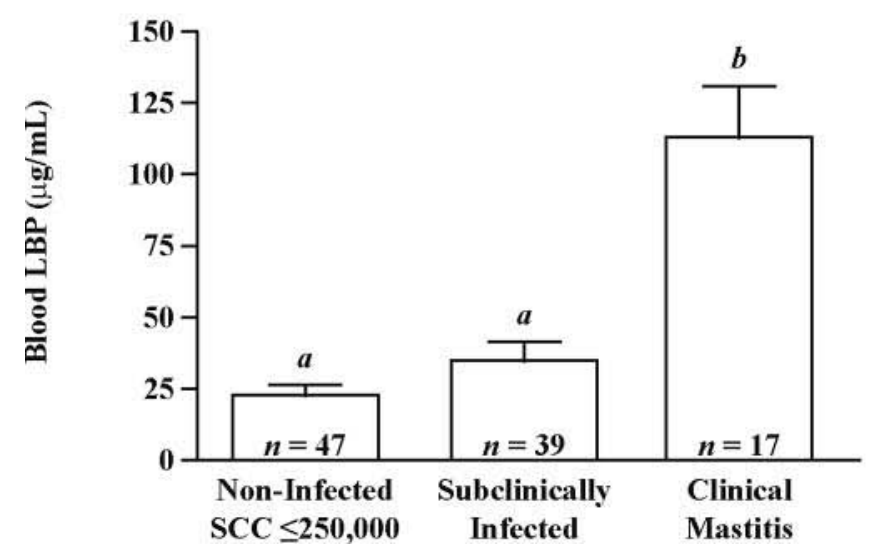

B

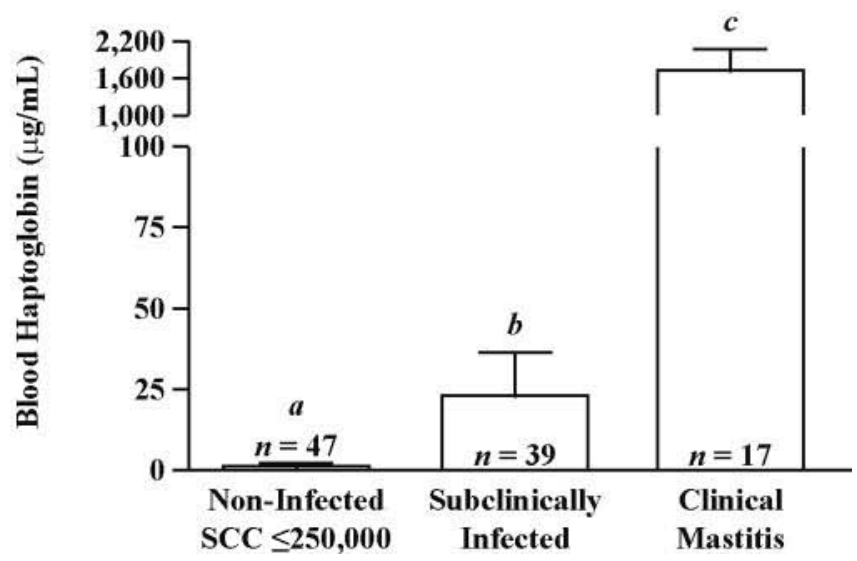

Figure 6. Measurement of acute phase protein concentrations in blood samples obtained from cows with subclinical intramammary infections or clinical mastitis. Blood samples were obtained from 1) clinically healthy cows that were free of infection and had milk SCC $<250,000$ cells/mL in all quarters; 2) clinically healthy cows with at least one quarter that was subclinically infected; and 3) cows that had at least one quarter diagnosed with clinical mastitis. The LPS-binding protein (LBP) (A) and haptoglobin (B) plasma concentrations were determined by ELISA and reported as mean $( \pm \mathrm{SE})$ concentrations in micrograms per milliliter. ${ }^{\mathrm{a}-\mathrm{C}}$ Different letters denote statistically significant $(P<0.05)$ differences between groups.

Consistent with these studies, milk haptoglobin concentrations were increased in quarters that were subclinically infected or showed clinical signs (Figure $4 \mathrm{~A}$ and 5D). Similar to LBP, milk haptoglobin concentrations differed between noninfected and infected quarters with low SCC (Figure 4C). In contrast to LBP, milk haptoglobin concentrations in clinical quarters approached a level that statistically differed $(P=0.0666)$ from that in subclinically infected quarters (Figure 5D). In further contrast to LBP, blood concentrations of haptoglobin were greater in cows with a subclinical infection than in those with all healthy quarters (Figure 6). Blood concentrations of haptoglobin were greater in cows with clinical mastitis than in cows with either a subclinical intramammary infection or all healthy quarters, a finding comparable to LBP.

During clinical mastitis, increased hepatic synthesis of APP and inflammation-induced vascular permeability are most likely to be the predominant events contributing to increased milk concentrations of LBP and haptoglobin (Riollet et al., 2000; Bannerman et al., 2003, 2004). However, the possibility that these APP may originate from the mammary gland cannot be excluded. Epithelial cells of the respiratory and intestinal tracts have been demonstrated to produce LBP in response to proinflammatory cytokines that are upregulated during mastitis (Vreugdenhil et al., 1999; Dentener et al., 2000; Bannerman et al., 2004). Thus, one cannot rule out the possibility that the mammary epithelium is equally capable of serving as a local source of LBP. It is known that bovine mammary epithelial cells can synthesize haptoglobin (Thielen et al., 2007). Moreover, haptoglobin is synthesized and stored in the specific granules of neutrophils (Cooray et al., 2007). Because milk concentrations of neutrophils can approach $5 \times$ $10^{7}$ cells $/ \mathrm{mL}$ during mastitis (Bannerman et al., 2004), one cannot exclude these cells as contributing sources of haptoglobin within the inflamed gland.

To our knowledge, this is the first study to evaluate milk and blood concentrations of LBP in cows with naturally occurring mastitis. Specifically, this study demonstrated that 1) LBP concentrations are increased in the milk and blood of quarters and cows, respectively, with clinical mastitis; 2) in clinically healthy cows with quarters with low SCC, milk concentrations of LBP are increased in quarters with subclinical infections; and 3) in clinically healthy cows, milk LBP concentrations are greater in quarters with SCC $>250,000$ cells/ $\mathrm{mL}$ than in those with lower SCC. In contrast to the APP haptoglobin, blood concentrations of LBP in cows with a subclinical intramammary infection could not be differentiated from those of cows with all healthy quarters. Thus, although previous studies have demonstrated a more rapid and prolonged induction of LBP in response to experimental intramammary infection than other APP, data from this study suggest that blood haptoglobin may be a better biomarker than LBP for differentiating healthy and subclinically infected cows. Further studies are warranted to investigate the utility of LBP as a diagnostic marker of intramammary infection status. By using a larger sample size, future studies could advance the findings reported here by looking at 
the influence of etiological agent on LBP concentrations and comparing the sensitivity and specificity of LBP and other APP to diagnose subclinical mastitis.

\section{REFERENCES}

Bannerman, D. D., A. Chockalingam, M. J. Paape, and J. C. Hope. 2005. The bovine innate immune response during experimentallyinduced Pseudomonas aeruginosa mastitis. Vet. Immunol. Immunopathol. 107:201-215.

Bannerman, D. D., A. C. Kauf, M. J. Paape, H. R. Springer, and J. P. Goff. 2008. Comparison of Holstein and Jersey innate immune responses to Escherichia coli intramammary infection. J. Dairy Sci. 91:2225-2235.

Bannerman, D. D., M. J. Paape, W. R. Hare, and E. J. Sohn. 2003. Increased levels of LPS-binding protein in bovine blood and milk following bacterial lipopolysaccharide challenge. J. Dairy Sci. 86:3128-3137.

Bannerman, D. D., M. J. Paape, J. W. Lee, X. Zhao, J. C. Hope, and P. Rainard. 2004. Escherichia coli and Staphylococcus aureus elicit differential innate immune responses following intramammary infection. Clin. Diagn. Lab. Immunol. 11:463-472.

Bradley, A. J., K. A. Leach, J. E. Breen, L. E. Green, and M. J. Green. 2007. Survey of the incidence and aetiology of mastitis on dairy farms in England and Wales. Vet. Rec. 160:253-257.

Cooray, R., K. P. Waller, and P. Venge. 2007. Haptoglobin comprises about $10 \%$ of granule protein extracted from bovine granulocytes isolated from healthy cattle. Vet. Immunol. Immunopathol. 119:310-315

Dentener, M. A., A. C. Vreugdenhil, P. H. Hoet, J. H. Vernooy, F. H. Nieman, D. Heumann, Y. M. Janssen, W. A. Buurman, and E. F. Wouters. 2000. Production of the acute-phase protein lipopolysaccharide-binding protein by respiratory type II epithelial cells: Implications for local defense to bacterial endotoxins. Am. J. Respir. Cell Mol. Biol. 23:146-153.

Dinarello, C. A. 1997. Proinflammatory and anti-inflammatory cytokines as mediators in the pathogenesis of septic shock. Chest 112:321S-329S.

Dohoo, I. R., and A. H. Meek. 1982. Somatic cell counts in bovine milk. Can. Vet. J. 23:119-125.

Eckersall, P. D., F. J. Young, C. McComb, C. J. Hogarth, S. Safi, A. Weber, T. McDonald, A. M. Nolan, and J. L. Fitzpatrick. 2001. Acute phase proteins in serum and milk from dairy cows with clinical mastitis. Vet. Rec. 148:35-41.

Fan, X., F. Stelter, R. Menzel, R. Jack, I. Spreitzer, T. Hartung, and C. Schutt. 1999. Structures in Bacillus subtilis are recognized by CD14 in a lipopolysaccharide binding protein-dependent reaction. Infect. Immun. 67:2964-2968.

Gronlund, U., C. Hallen Sandgren, and K. Persson Waller. 2005. Haptoglobin and serum amyloid A in milk from dairy cows with chronic sub-clinical mastitis. Vet. Res. 36:191-198.

Hirvonen, J., K. Eklund, A. M. Teppo, G. Huszenicza, M. Kulcsar, H. Saloniemi, and S. Pyorala. 1999. Acute phase response in dairy cows with experimentally induced Escherichia coli mastitis. Acta Vet. Scand. 40:35-46.

Hiss, S., U. Mueller, A. Neu-Zahren, and H. Sauerwein. 2007. Haptoglobin and lactate dehydrogenase measurements in milk for the identification of subclinically diseased udder quarters. Vet. Med. (Praha) 52:245-252.

Horadagoda, N. U., P. D. Eckersall, L. Andrew, P. Gallay, D. Heumann, and H. A. Gibbs. 1995. Characterisation of bovine lipopolysaccharide binding protein and the in vivo acute phase response to Pasteurella haemolytica Type A. Vet. Immunol. Immunopathol. 49:61-74.

Kauf, A. C., R. F. Rosenbusch, M. J. Paape, and D. D. Bannerman. 2007. Innate immune response to intramammary Mycoplasma bovis infection. J. Dairy Sci. 90:3336-3348.
Makovec, J. A., and P. L. Ruegg. 2003. Results of milk samples submitted for microbiological examination in Wisconsin from 1994 to 2001. J. Dairy Sci. 86:3466-3472.

National Mastitis Council. 1999. Laboratory Handbook on Bovine Mastitis. The National Mastitis Council Inc., Madison, WI.

Nielsen, B. H., S. Jacobsen, P. H. Andersen, T. A. Niewold, and P. M. Heegaard. 2004. Acute phase protein concentrations in serum and milk from healthy cows, cows with clinical mastitis and cows with extramammary inflammatory conditions. Vet. Rec. 154:361-365.

Ohtsuka, H., K. Kudo, K. Mori, F. Nagai, A. Hatsugaya, M. Tajima, K. Tamura, F. Hoshi, M. Koiwa, and S. Kawamura. 2001. Acute phase response in naturally occurring coliform mastitis. J. Vet. Med. Sci. 63:675-678.

Pannen, B. H., and J. L. Robotham. 1995. The acute-phase response. New Horiz. 3:183-197.

Pedersen, L. H., B. Aalbaek, C. M. Rontved, K. L. Ingvartsen, N. S. Sorensen, P. M. Heegaard, and H. E. Jensen. 2003. Early pathogenesis and inflammatory response in experimental bovine mastitis due to Streptococcus uberis. J. Comp. Pathol. 128:156164

Riollet, C., P. Rainard, and B. Poutrel. 2000. Differential induction of complement fragment C5a and inflammatory cytokines during intramammary infections with Escherichia coli and Staphylococcus aureus. Clin. Diagn. Lab. Immunol. 7:161-167.

SAS Institute. 2006. The GLIMMIX procedure. http://support.sas. com/rnd/app/papers/glimmix.pdf. Accessed July 1, 2008.

Schepers, A. J., T. J. Lam, Y. H. Schukken, J. B. Wilmink, and W. J. Hanekamp. 1997. Estimation of variance components for somatic cell counts to determine thresholds for uninfected quarters. J. Dairy Sci. 80:1833-1840.

Schroder, N. W., S. Morath, C. Alexander, L. Hamann, T. Hartung, U. Zahringer, U. B. Gobel, J. R. Weber, and R. R. Schumann. 2003. Lipoteichoic acid (LTA) of Streptococcus pneumoniae and Staphylococcus aureus activates immune cells via Toll-like receptor (TLR)-2, lipopolysaccharide-binding protein (LBP), and CD14, whereas TLR-4 and MD-2 are not involved. J. Biol. Chem. 278:15587-15594.

Schroedl, W., B. Fuerll, P. Reinhold, M. Krueger, and C. Schuett. 2001. A novel acute phase marker in cattle: Lipopolysaccharide binding protein (LBP). J. Endotoxin Res. 7:49-52.

Schukken, Y. H., D. J. Wilson, F. Welcome, L. Garrison-Tikofsky, and R. N. Gonzalez. 2003. Monitoring udder health and milk quality using somatic cell counts. Vet. Res. 34:579-596.

Schumann, R. R., and E. Latz. 2000. Lipopolysaccharide-binding protein. Chem. Immunol. 74:42-60.

Suffredini, A. F., G. Fantuzzi, R. Badolato, J. J. Oppenheim, and N. P. O'Grady. 1999. New insights into the biology of the acute phase response. J. Clin. Immunol. 19:203-214.

Thielen, M. A., M. Mielenz, S. Hiss, H. Zerbe, W. Petzl, H. J. Schuberth, H. M. Seyfert, and H. Sauerwein. 2007. Short communication: Cellular localization of haptoglobin mRNA in the experimentally infected bovine mammary gland. J. Dairy Sci. 90:1215-1219.

Tobias, P. S., R. I. Tapping, and J. A. Gegner. 1999. Endotoxin interactions with lipopolysaccharide-responsive cells. Clin. Infect. Dis. 28:476-481.

Vreugdenhil, A. C., M. A. Dentener, A. M. Snoek, J. W. Greve, and W. A. Buurman. 1999. Lipopolysaccharide binding protein and serum amyloid A secretion by human intestinal epithelial cells during the acute phase response. J. Immunol. 163:2792-2798.

Vreugdenhil, A. C., C. H. Rousseau, T. Hartung, J. W. Greve, C. Van't Veer, and W. A. Buurman. 2003. Lipopolysaccharide (LPS)binding protein mediates LPS detoxification by chylomicrons. J. Immunol. 170:1399-1405.

Westfall, P. H., and R. D. Tobias. 2007. Multiple testing of general contrasts: Truncated closure and the extended Shaffer-Royen method. J. Am. Stat. Assoc. 102:487-494.

Wurfel, M. M., S. T. Kunitake, H. Lichenstein, J. P. Kane, and S. D. Wright. 1994. Lipopolysaccharide (LPS)-binding protein is carried on lipoproteins and acts as a cofactor in the neutralization of LPS. J. Exp. Med. 180:1025-1035. 